Л.К. ОВСЯННИКОВА, канд. техн. наук, доцент, О.Г. СОКОЛОВСЬКА, канд. техн. наук, Л.О. ВАЛЕВСЬКА, канд. техн. наук, доцент, Ю.В. ГРИЩУК, аспірант

\title{
ВИЗНАЧЕННЯ ФАКТОРІВ, ЩО ВПЛИВАЮТЬ НА ОРГАНІЗАЦІЮ ПРОЦЕСУ ЗБЕРІГАННЯ ДРІБНОНАСТННЕВИХ ОЛІЙНИХ КУЛЬТУР
}

\section{Анотація}

В статті проведено дослідження зміни кислотного, перекисного та йодного чисел дрібнонасіннсвих олійних культур у діапазоні температури зберігання $5 \ldots 25{ }^{\circ} \mathrm{C}$ та тривалості зберігання до 12 місяців. Встановлено, щзо з факторів, що впливають на величину поглинання води насінням, визначаючими є анатомічна будова і хімічний склад зерна. При однакових температурі і відносній вологості повітря основні і покривні тканини насіння поглинають з повітря різну кількість вологи.

Показано, що чим вище олійність насіння, тим нижче їх рівноважна вологість, тому у високоолійному насінні вміст вологи в гідрофільній частині вищий. Для олійного насіння вологість гідрофільної частини значно вище за сумарну вологість. Хімічний склад гідрофільної частини насіння різних культур різний, тому їх вологопоглинаюча здатність не однакова. Проте в цілому для всіх культур загальна зворотна залежність між вмістом олії в насінні і рівноважною вологістю зберігається.

Величина рівноважної вологості насіння залежить від розмірів насіння: рівноважна вологість у дрібного насіння менше, ніж у крупних, унаслідок відносного збільшеної поверхні насіння.

Отримані дані можна використовувати при виборі умов при закладанні дрібнонасіннєвих олійних культур на довготривале зберігання.

Для зберігання насіння олійних культур має значення не тільки вміст сирого жиру, а також жирокислотний склад оліі, пери за все вміст ненасичених жирних кислот. Псування макової олії при несприятливих умовах зберігання починається під впливом ферменту ліпази, яка розщеплюе жир на глічерин і вільні жирні кислоти. Вільні жирні кислоти можуть вступати в реакцію з киснем i далі розщеплюватися, при цьому утворюються проміжні продукти - гідроперекиси, які можуть руйнуватися далі до альдегідів, кетонів та простих жирних кислот. Саме вторинні продукти окислення зумовлюють зниження харчової иінності олії і ї̈ псування. Окислювальні прочеси протікають в основному в ненасичених жирних кислотах, а жирокислотний склад насіння муку на 90 \% складається з ненасичених жирних кислот.

При зберіганні дрібнонасіннєвих культур протягом 12 місяиів показники їх якості не перевищували нормованих значень.

Ключові слова: дрібнонасіннєві культури, гігроскопічні властивості, рівноважна вологість, показники якості, режими зберігання.

Вступ

Основним завданням технології післязбиральної обробки є доведення зерна до стану, при якому його можна зберігати тривалий час без втрат в масі i погіршення якості. Збереженість зерна до його реалізації - досить складне завдання, особливо останніми роками, коли більшість сільськогосподарських виробників зберігають збіжжя безпосередньо в господарстві.

Виробництво зернових та олійних культур в значній мірі залежить від завдань, що ставить агропромисловий комплекс України, при цьому не менш важлива роль належить питанням зберігання зерна, як для внутрішнього споживання (продовольчі, кормові цілі), так і для розв'язання комерційних задач експорту зерна. Відомо, що такі дрібнонасіннєві культури, як льон, гірчиця, мак та ін. $є$ перспективними та високорентабельними. Отже розробка та уточнення режимів зберігання для цих культур є досить актуальним.

Труднощі в організації зберігання дрібонасіннєвих культур зумовлюються їх фізіологічними та біохімічними властивостями.

Важливий вплив на стан зернової маси при зберіганні i, особливо, при первинній обробці має іiі гігроскопічність, тобто здатність до сорбції і десорбції парів води. Зволоження зерна в результаті сорбції під час зберігання створює умови для підвищення життєдіяльності насіння, мікроорганізмів та інших живих організмів, а знання рівноважної вологості дозволяє встановити умови безпечного зберігання зерна.

Важливий вплив на стан зернової маси при зберіганні і, особливо, при післязбиральній обробці має іiі гігроскопічність, тобто здатність до сорбції i десорбції парів води. Зволоження зерна в результаті сорбції під час зберігання створює умови для підвищення життєдіяльності насіння, мікроорганізмів та інших живих організмів [1-5].

В процесі зберігання зерна важливе значення має сорбція (десорбція) парів води, оскільки маса сорбованої води визначає вологість продукту, від якої в свою чергу, суттєво залежать фізичні і технологічні властивості зерна і зернопродуктів. Зернини всіх культур, як гігроскопічні речовини, поглинають пару води 3 навколишнього середовища. Кількість вологи, що поглинається, залежить від таких основних факторів, як температура та відносна вологість зовнішнього повітря, вид зернової культури та іï вологість $[3,5,6]$.

Зерно і насіння усіх культур вбирає 3 довкілля пари різних речовин і газу (сорбція) i, навпаки, за певних умов виділяє їх, особливо воду (десорбція). У зерновій масі спостерігається адсорбція, абсорбція, 
капілярна конденсація і хемосорбція. Здатність зерна до сорбції зумовлена його капілярнопористою колоїдною структурою і шпаруватістю маси. Встановлено, що лише за рахунок макро- та мікрокапілярів поверхня зерна збільшується у 20 разів порівняно з власною поверхнею.

Зерно - це живий організм, тому вологообмін між зерновою масою і повітрям відбувається безперервно. Спрямованість і інтенсивність сорбції парів води залежить від тиску водяних парів у навколишньому повітрі та на поверхні зерна [5-10]. Залежно від параметрів повітря (його вологості і температури) і стану зернової маси, вологообмін проходить у двох протилежних напрямках:

- передача вологи від зерна до повітря. Таке явище (десорбція) спостерігається, коли парціальний тиск водяних парів біля поверхні зерна більший від парціального тиску водяних парів у повітрі;

- зволоження зерна внаслідок поглинання (сорбція) вологи 3 навколишнього повітря. Цей процес відбувається, якщо парціальний тиск водяних парів біля поверхні зерна менший від парціального тиску водяних парів у повітрі. Вологообмін між повітрям і зерном припиняється, якщо парціальний тиск водяних парів у повітрі і над зерном однаковий. При цьому настає стан динамічної рівноваги. Вологість зерна, яка відповідає такому стану, називають рівноважною. Вологообмін між повітрям і зерном припиняється, коли парціальні тиски водяної пари в повітрі і над зерном однакові. В цьому випадку наступає стан динамічної рівноваги. Вологість зерна, яка відповідає цьому стану, називається рівноважною вологістю $[1,3,5]$. У насінні олійних культур рівноважна вологість в 2 рази нижча, ніж у зернових, оскільки жир не гідрофільна речовина i, тому, насіння олійних культур менше поглинає вологу.

Важливий вплив на стан зернової маси при зберіганні має її гігроскопічність, тобто здатність до сорбції і десорбції парів води. Зволоження зерна в результаті сорбції під час зберігання створює умови для підвищення життєдіяльності насіння, мікроорганізмів та інших живих організмів $[5,6,10]$.

Олійні культури на відміну від зернових культур мають свої характерні особливості, від яких залежать режими зберігання і обробки насіння. В літературних джерелах дуже мало даних стосовно гігроскопічних властивостей дрібнонасіннєвих культур, а для деяких зовсім відсутні (наприклад, мак), також існуючі дані не дають повної картини впливу умов зберігання та вологості зерна на гігроскопічні властивості.

Слід зазначити, що сорбція та десорбція вологи зерном частіше спостерігається під час збирання врожаю. Рівноважна вологість зерна залежить від температури повітря, вона збільшується зі зниженням температури повітря. Також рівноважна вологість зерна залежить від його хімічного складу і насіння. Так, у насінні олійних культур за усіх інших однакових умов рівноважна вологість майже вдвічі менша, ніж у зернових. Це пояснюється меншим вмістом у насінні олійних культур гідрофільних колоїдів і більшим вмістом жиру, який не володіє гігроскопічними властивостями. Тому, чим більший вміст олії, тим менша їх рівноважна вологість. На рівноважну вологість зерна, крім його хімічного складу, структури і параметрів навколишнього повітря, впливає також явище сорбційного гістерезису, що проявляється в несумісності ізотерм сорбції і десорбції. Для зерна і продуктів його переробки ізотерма десорбції в системі координат розміщується вище, ніж ізотерма сорбції. Тому вологість зерна, що визначається за ізотермою сорбції, завжди буде меншою, ніж за ізотермою десорбції, для однієї й тієї ж відносної вологості повітря. Тобто якщо зерно після сушіння знову піддати зволоженню, то для одержання тієї ж рівноважної вологості [4, 6, 8-10].

У результаті сорбційного гістерезису різниця рівноважної вологості за ізотермами досягає у середньому $1,2 \ldots 1,3 \%$. У зв'язку 3 явищем сорбційного гістерезису в зерновій масі ніколи не спостерігається повного вирівнювання вологості між окремими зернами. Цю обставину слід ураховувати у практиці зберігання й обробки зернових мас. Причинами нерівномірного розподілу вологи в зерновій масі можуть бути:

- нерівномірний розподіл вологи в кожному окремо взятому зерні;

- різна сорбційна ємність зерен різної виповненості і крупності;

- відносна вологість навколишнього повітря зернової маси;

- виділення води і тепла усіма живими компонентами зернової маси;

- стан зерносховищ.

У процесі зберігання олійних культур основним видом їхнього псування $є$ процес прогіркання жирів, що супроводжується утворенням альдегідів, кетонів, перекисів, що надають продукту неприємний запах і смак, а також погіршує їхні органолептичні властивості. Основними показниками якості жирів $є$ їхні кислотне, перекисне і йодне числа [12-14].

В літературних джерелах дуже мало даних стосовно гігроскопічних властивостей дрібнонасіннєвих олійних культур, а для деяких зовсім відсутні (наприклад, мак), також існуючі дані не дають повної картини впливу умов зберігання та вологості зерна на гігроскопічні властивості.

Таким чином, давно відомим дрібнонасіннєвим олійним культурам, як ріпак, гірчиця, льон та іншим, необхідно приділити значну увагу. Свіжозібрані дрібнонасіннєві культури, як правило, мають підвищену вологість, що може за кілька годин призвести до їх самозігрівання і псування. Для обгрунтування методів та режимів активного вентилювання i сушіння дрібнонасіннєвих культур, особливе значення мають масообмінні (гігроскопічні) властивості. Гігроскопічні властивості мають також особливе значення для обгрунтування методів та режимів активного вентилювання і сушіння зерна. Так, рівноважна вологість дозволяє оцінити потенційну здатність повітря як агента активного вентилювання або сушіння, а також встановити умови безпечного зберігання зерна. Аналіз літературних даних показав, що вказані характеристики для більшості згаданих дрібнонасіннєвих культур або зовсім не вивчені, або наведені для 
вузького діапазону зміни параметрів навколишнього середовища.

Метою даного дослідження стало встановлення ефективних режимів зберігання дрібнонасіннєвих олійних культур, що дозволять поліпшити якість та забезпечити довготривале гарантоване зберігання.

Аналіз літературних даних показав, що гігроскопічні властивості дрібнонасіннєвих олійних культур або зовсім не вивчені, або наведені для вузького діапазону зміни параметрів навколишнього середовища. Це дозволило сформувати наступні задачі досліджень:

- визначити вплив відносної вологості повітря, температурі повітря та вологості зерна на гігроскопічні властивості;

- визначити якість зерна дрібнонасіннєвих олійних культур при різних умовах зберігання;

- визначити вплив умов зберігання на якість дрібнонасііннєвих олійних культур.

Для визначення ефективних режимів зберігання зерна нами був проведений ряд дослідів 3 визначення рівноважної вологості.

Найбільш надійним і швидким методом визначення рівноважної вологості є динамічний метод $[15,16]$. Сутність методу у тому, що крізь зразок зерна проходить потоком повітря певної відносної вологості.

Дослідження проводили при відносній вологості повітря 20..90\% і температури повітря від $0^{\circ}$ до $30^{\circ} \mathrm{C}$.

Вологість зерна вибирали таким чином, що вона відповідала за ДСТУ станом зерна за вологістю: сухе, середньої сухості, вологе та сире.

Контроль за якістю зерна дрібнонасіннєвих олійних культур у процесі зберігання здійснювали за основними показниками якості жирів: кислотне число (КЧ, мг КОН/г), перекисне число (ПЧ, моль $\mathrm{O}_{2} /$ кг), йодне число (IЧ, г $\mathrm{J}_{2}$ на 100 г жиру). Визначення кислотного, йодного та перекисного чисел насіння маку при зберіганні та вихідного зразка проводили відповідно ДСТУ ISO 660:2009, ДСТУ ISO 3961:2004, ДСТУ ISO 3960-2001.

Нормовані значення фізико-хімічних показників олії досліджених дрібнонасіннєвих культур наведено у табл. 1.

\section{Результати досліджень}

Нами проведено дослідження зміни кислотного, перекисного та йодного чисел дрібнонасіннєвих олійних культур у діапазоні температури зберігання $5 \ldots 25^{\circ} \mathrm{C}$ та тривалості зберігання до 12 місяців.
Відповідно обраному плану експерименти (досліди) проводили в декількох паралелях. Для виключення впливу неврахованих випадкових впливів досліди ранжували, тобто черговість їхньої реалізації визначали не порядком у плані експериментів, а за таблицями випадкових чисел, наведеними у спеціальній літературі [17]. Після виконання всіх дослідів плану експериментів проводили статистичну оцінку отриманих результатів, яка зводиться до виключення грубих похибок дослідів, обчисленню середніх за дослідами значень спостережень, визначенню вибіркових дисперсій для оцінки випадкових похибок, а також обчисленню відносних похибок i ряду інших статистичних характеристик.

Для чисельної оцінки коефіцієнтів в емпіричних математичних формулах використовували метод найменших квадратів. Обчислення коефіцієнтів у рівняннях математичних моделей проводили на ЕОМ за стандартними програмами та програмами, розробленим на кафедрі технології зберігання зерна OHAXT [17].

Згідно задач досліджень на першому етапі роботи проводились дослідження гігроскопічних властивостей дрібнонасіннєвих олійних культур.

Рівноважна вологість є однією 3 основних характеристик гігроскопічних зерна. Коли парціальні тиски парів біля поверхні зерна і в повітрі стають рівними наступає стан динамічної рівноваги. Вологість матеріалу яка відповідає стану рівноваги називається рівноважною.

Результати досліджень гігроскопічних властивостей дрібнонасіннєвих олійних культур наведено у табл. 2.

Найбільш повною характеристикою гігроскопічних властивостей $є$ ізотерма сорбції - залежність рівноважної вологості насіння $w_{\mathrm{p}}$ від відносноївологості повітря $\varphi$. Різні культури за одних і тих самих умов поглинають неоднакову кількість вологи, що пов'язано з будовою та біохімічним складом зерна $[1,3,14]$.

На величину і швидкість досягнення рівноважної вологості впливає величина відносної вологості повітря чим вона більша тим швидше зерно поглинає вологу і тим більша рівноважна вологість.

Значний вплив має і температура при одній і тій же відносній вологості повітря більш високій температурі відповідає більш низька рівноважна вологість і навпаки знижена температура призводить до підвищення рівноважної вологості зерна. Встановлено, що при всіх досліджуваних значеннях вологості насіння рівноважна вологість при температурі повітря $0{ }^{\circ} \mathrm{C}$ має найбільше значення, найменше значення при

Таблиця 1 - Нормовані значення фізико-хімічних показників олії досліджених дрібнонасіннєвих культур

\begin{tabular}{|c|c|c|c|c|}
\hline Олія & Літературні джерела & $\begin{array}{l}\text { Кислотне число КЧ, } \\
\text { мг КОН/г, не більше }\end{array}$ & $\begin{array}{c}\text { Перекисне число ПЧ, } \\
\mathrm{O}_{2} / \text { кг,не більше }\end{array}$ & $\begin{array}{c}\text { Йодне число ЙЧ, } \\
\mathrm{I}_{2} / 100 \text { г }\end{array}$ \\
\hline Ріпакова & ДСТУ ISO 150-2002 & 6,0 & 10 & $94 \ldots 106$ \\
\hline Гірчична & ДСТУ 4598:2006 & 6,0 & 10 & $92 \ldots 123$ \\
\hline Лляна & ДСТУ 46.072:2003 & 5,0 & 10 & $170 \ldots 200$ \\
\hline Макова & $\begin{array}{l}\text { TУ У15.4-32448339- } \\
01: 2007\end{array}$ & 6,0 & 10 & $130 \ldots 160$ \\
\hline
\end{tabular}


Таблиця 2 - Рівноважна вологість деяких олійних дрібнонасіннєвих культур $(n=3, p \geq 0,95)$

\begin{tabular}{|c|c|c|c|c|c|c|c|c|c|c|}
\hline \multirow{2}{*}{ Культура } & \multirow{2}{*}{$\begin{array}{c}\text { Вологість } \\
\text { зерна, \% }\end{array}$} & \multirow{2}{*}{$\begin{array}{l}\text { Температура } \\
\text { повітря, }{ }^{\circ} \mathrm{C}\end{array}$} & \multicolumn{8}{|c|}{ Відносна вологість повітря, \% } \\
\hline & & & 20 & 30 & 40 & 50 & 60 & 70 & 80 & 90 \\
\hline \multirow{9}{*}{ Ріпак } & \multirow[t]{3}{*}{7,2} & 30 & 5,93 & 6,11 & 6,45 & 6,98 & 7,31 & 7,94 & 8,58 & 9,14 \\
\hline & & 20 & 6,09 & 6,27 & 6,67 & 7,18 & 7,57 & 8,18 & 8,78 & 9,39 \\
\hline & & $\overline{00}$ & 6,18 & 6,40 & 6,96 & 7,52 & 8,09 & 8,69 & 9,17 & 9,56 \\
\hline & \multirow[t]{3}{*}{12,0} & 30 & 6,08 & 6,24 & 6,52 & 7,04 & 7,43 & 8,37 & 8,69 & 9,23 \\
\hline & & 20 & 6,15 & 6,37 & 6,78 & 7,16 & 7,58 & 8,45 & 8,84 & 9,53 \\
\hline & & 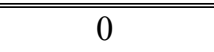 & 6,29 & 6,53 & 7,05 & 7,67 & 8,21 & 8,74 & 9,16 & 9,79 \\
\hline & \multirow[t]{3}{*}{16,0} & 30 & 6,19 & 6,37 & 6,85 & 7,19 & $7 \overline{7,57}$ & 8,48 & 8,90 & 9,34 \\
\hline & & 20 & 6,31 & $\overline{6,55}$ & 7,05 & $\overline{7,47}$ & $7,7,84$ & 8,58 & 9,14 & 9,67 \\
\hline & & 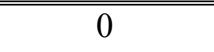 & 6,53 & 6,98 & 7,40 & $7,7,58$ & $7 \overline{7,96}$ & 8,87 & 9,39 & 10,1 \\
\hline \multirow{9}{*}{ Гірчиця } & \multirow[t]{3}{*}{$\overline{77,0}$} & 30 & 6,05 & 6,20 & 6,83 & $7 \overline{7,21}$ & $7 \overline{7,65}$ & 8,38 & 8,85 & 9,57 \\
\hline & & 20 & 6,17 & 6,57 & 7,08 & 7,38 & 7,71 & 8,47 & 9,17 & 9,70 \\
\hline & & $\begin{array}{l}0 \\
\end{array}$ & 6,24 & 6,72 & 7,28 & 7,51 & $7,7,86$ & 8,56 & 9,37 & 9,89 \\
\hline & \multirow[t]{3}{*}{ 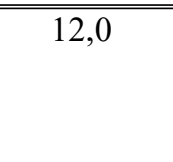 } & 30 & 6,13 & 6,31 & 6,96 & 7,36 & 7,78 & 8,42 & 8,96 & 9,62 \\
\hline & & 20 & 6,25 & 6,65 & 7,25 & 7,42 & $7,7,88$ & 8,65 & $9,9,22$ & 9,80 \\
\hline & & 0 & 6,37 & 6,87 & 7,37 & 7,64 & 8,09 & 8,85 & 9,44 & 9,97 \\
\hline & \multirow[t]{3}{*}{16,0} & 30 & 6,27 & 6,44 & 7,07 & 7,49 & 7,86 & 8,53 & 9,11 & 9,68 \\
\hline & & 20 & 6,40 & 6,81 & 7,37 & 7,75 & 8,14 & 8,73 & 9,38 & 10,0 \\
\hline & & 0 & 6,63 & 7,21 & 7,57 & 7,94 & 8,32 & 8,97 & $9,9,64$ & 10,4 \\
\hline \multirow{9}{*}{$\begin{array}{l}\text { Льон } \\
\text { олійний }\end{array}$} & \multirow[t]{3}{*}{6,7} & 30 & 5,23 & 5,51 & 5,87 & 6,30 & 6,84 & 7,66 & 8,36 & 9,37 \\
\hline & & 20 & 5,35 & 5,64 & $\overline{6,03}$ & 6,67 & $\overline{7,23}$ & 7,88 & $\overline{8,63}$ & $\overline{9,57}$ \\
\hline & & 0 & 5,68 & $\overline{5,93}$ & 6,28 & 6,81 & 7,65 & $\overline{8,33}$ & 9,26 & 10,12 \\
\hline & \multirow[t]{3}{*}{12,0} & 30 & 5,28 & 5,54 & 5,90 & 6,41 & 6,92 & 7,72 & 8,41 & 9,45 \\
\hline & & 20 & 5,45 & 5,67 & 6,03 & 6,52 & 7,28 & 7,94 & 8,68 & 9,62 \\
\hline & & 0 & 5,76 & $\overline{6,12}$ & 6,92 & 7,17 & 7,94 & $\overline{8,57}$ & 9,44 & 10,36 \\
\hline & \multirow[t]{3}{*}{16,0} & 30 & 5,32 & $\overline{5,61}$ & 6,02 & 6,53 & $\overline{7,06}$ & $\overline{7,98}$ & $\overline{8,61}$ & 9,57 \\
\hline & & 20 & 5,49 & 5,72 & 6,19 & $\overline{6,6,67}$ & 7,4 & 8,11 & 8,75 & 9,76 \\
\hline & & 0 & 5,92 & 6,11 & 6,47 & 7,24 & 8,05 & 8,73 & 9,63 & 10,57 \\
\hline \multirow{9}{*}{ Мак } & \multirow[t]{3}{*}{6,3} & 30 & 3,95 & 4,56 & 5,08 & 5,57 & 6,07 & 6,59 & 7,20 & 8,02 \\
\hline & & 20 & 4,37 & 4,98 & 5,51 & 5,999 & $6,4,48$ & 6,99 & $7 \overline{7,58}$ & 8,37 \\
\hline & & $\overline{0}$ & 4,86 & 5,35 & 6,11 & 6,63 & $7 \overline{7,14}$ & 7,68 & $8,8,30$ & 9,14 \\
\hline & \multirow[t]{3}{*}{10,5} & 30 & 4,21 & 4,88 & 5,45 & 6,00 & 6,54 & 7,12 & $7,7,79$ & 8,71 \\
\hline & & 20 & 4,31 & $\overline{5,00}$ & 5,59 & 6,15 & 6,72 & $\overline{7,32}$ & 8,02 & 8,97 \\
\hline & & 0 & 4,98 & 5,55 & 6,15 & 6,72 & 7,27 & 7,86 & 8,54 & 9,46 \\
\hline & \multirow[t]{3}{*}{$\begin{array}{ll}14,3 \\
\end{array}$} & 30 & 4,49 & 5,21 & 5,85 & 6,45 & 7,06 & $\overline{7,71}$ & 8,46 & 9,49 \\
\hline & & 20 & 6,40 & 6,81 & 7,37 & 7,75 & 8,14 & 8,73 & 9,38 & 10,0 \\
\hline & & 0 & 6,63 & 7,21 & 7,57 & 7,94 & 8,32 & 8,97 & 9,64 & 10,4 \\
\hline
\end{tabular}

температурі $30^{\circ} \mathrm{C}$.

3 факторів, що впливають на величину поглинання води насінням, визначаючими $є$ анатомічна будова і хімічний склад зерна. При однакових температурі і відносній вологості повітря основні і покривні тканини насіння поглинають 3 повітря різну кількість вологи. Чим вище олійність насіння, тим нижче їх рівноважна вологість, тому у високоолійному насінні вміст вологи в гідрофільній частині вищий.
Для олійного насіння вологість гідрофільної частини значно вище за сумарну вологість. Хімічний склад гідрофільної частини насіння різних культур різний, тому їх вологопоглинаюча здатність не однакова. Проте в цілому для всіх культур загальна зворотна залежність між вмістом олії в насінні і рівноважною вологістю зберігається.

Величина рівноважної вологості насіння залежить від розмірів насіння: рівноважна вологість у 
дрібного насіння менше, ніж у крупних, унаслідок відносного збільшеної поверхні насіння.

Отримані дані можна використовувати при виборі умов при закладанні дрібнонасіннєвих культур на довготривале зберігання. Слід також остерігатись підвищення відносної вологості повітря понад 70 \% особливо в теплі періоди року оскільки це призводить до швидкого розвитку пліснявих грибів і активізації ферментного комплексу.

На другому етапі нашої роботи проведено дослідження зміни кислотного, перекисного та йодного чисел дрібнонасіннєвих олійних культур у діапазоні температури зберігання від 5 до $25{ }^{\circ} \mathrm{C}$ та тривалості зберігання до 12 місяців.

Кислотне число визначає кількість мг КОН, необхідне для нейтралізації вільних жирних кислот, що містяться в одному грамі жиру. Кислотне число в значній мірі характеризує якість жирів. Воно вказує на відносний вміст вільних жирних кислот $[12,13]$. Наявність значної кількості вільних жирних кислот

\section{Таблиця 3 - Показники якості дрібнонасіннсвих культур в залежності від} температури і тривалості зберігання

\begin{tabular}{|c|c|c|c|c|c|}
\hline Культура & $\begin{array}{c}\text { Температура } \\
\text { зберігання, }{ }^{\circ} \mathrm{C} \\
\end{array}$ & $\begin{array}{c}\text { Тривалість } \\
\text { зберігання, міс. }\end{array}$ & $\begin{array}{c}\text { Кислотне число, } \\
\text { мг КОН/г }\end{array}$ & $\begin{array}{c}\text { Йодне число, } \\
\mathrm{I}_{2} / 100 г \\
\end{array}$ & $\begin{array}{c}\text { Перекисне чис- } \\
\text { ло, моль } \mathrm{O}_{2} / \text { кг }\end{array}$ \\
\hline \multirow{9}{*}{ Ріпак } & \multirow{3}{*}{5} & 0 & 4,28 & 70,80 & 3,38 \\
\hline & & 6 & 4,49 & 73,25 & 3,65 \\
\hline & & 12 & 4,87 & 77,44 & 3,94 \\
\hline & \multirow{3}{*}{15} & 0 & 4,28 & 70,80 & 3,38 \\
\hline & & 6 & 4,68 & 76,02 & 3,70 \\
\hline & & 12 & 5,06 & 79,25 & 3,98 \\
\hline & \multirow{3}{*}{25} & 0 & 4,28 & 70,80 & 3,38 \\
\hline & & 6 & 4,79 & 78,26 & 3,75 \\
\hline & & 12 & 5,21 & 80,34 & 4,02 \\
\hline \multirow{9}{*}{ Гірчиця } & \multirow{3}{*}{5} & 0 & 3,61 & 55,86 & 1,82 \\
\hline & & 6 & 3,85 & 59,75 & 2,25 \\
\hline & & 12 & 4,12 & 65,87 & 2,78 \\
\hline & \multirow{3}{*}{15} & 0 & 3,61 & 55,86 & 1,82 \\
\hline & & 6 & 3,94 & 64,87 & 2,31 \\
\hline & & 12 & 4,56 & 69,12 & 2,85 \\
\hline & \multirow{3}{*}{25} & 0 & 3,61 & 55,86 & 1,82 \\
\hline & & 6 & 4,11 & 65,18 & 2,36 \\
\hline & & 12 & 4,85 & 72,24 & 2,97 \\
\hline \multirow{9}{*}{$\begin{array}{l}\text { Льон } \\
\text { олійний }\end{array}$} & \multirow{3}{*}{5} & 0 & 2,78 & 61,27 & 2,18 \\
\hline & & 6 & 2,97 & 65,15 & 2,49 \\
\hline & & 12 & 3,25 & 70,23 & 3,08 \\
\hline & \multirow{3}{*}{15} & 0 & 2,78 & 61,27 & 2,18 \\
\hline & & 6 & 3,04 & 68,14 & 2,56 \\
\hline & & 12 & 3,59 & 73,55 & 3,16 \\
\hline & \multirow{3}{*}{25} & 0 & 2,78 & 61,27 & 2,18 \\
\hline & & 6 & 3,11 & 70,26 & 2,74 \\
\hline & & 12 & 3,86 & 76,38 & 3,28 \\
\hline \multirow{9}{*}{ Мак } & \multirow{3}{*}{5} & 0 & 3,13 & 118,22 & 5,09 \\
\hline & & 6 & 3,36 & 121,34 & 5,36 \\
\hline & & 12 & 3,69 & 126,85 & 5,75 \\
\hline & \multirow{3}{*}{15} & 0 & 3,13 & 118,22 & 5,09 \\
\hline & & 6 & 3,47 & 123,56 & 5,46 \\
\hline & & 12 & 3,86 & 129,24 & 5,88 \\
\hline & \multirow{3}{*}{25} & 0 & 3,13 & 118,22 & 5,09 \\
\hline & & 6 & 3,54 & 126,57 & 5,59 \\
\hline & & 12 & 3,96 & 133,63 & 6,04 \\
\hline
\end{tabular}


небажана в харчових та технічних жирах, отже повинно бути невелике кислотне число.

Перекисне число служить показником окисних змін жиру $[12,13]$. У присутності кисню повітря, жирні кислоти, які входять до складу жирів, можуть частково окислятися та утворювати перекиси, і чим більшим $є$ процес окислювання, тим вищим буде перекисне число.

Йодне число показує, яка кількість грамів йоду може бути зв'язаною зі 100 грамами жиру. Йодне число - важлива константа, тому що воно характеризує ступінь ненасиченості кислот, які входять до складу даного жиру $[12,13]$. Високе йодне число вказує на значну кількість ненасичених жирних кислот, що робить олію особливо цінною при використанні іiі в технічних і харчових цілях. Зберігання дрібнонасіннєвих культур супроводжується зміною кислотного, перекисного та йодного чисел.

Результати досліджень хімічних показників олії насіння при зберігання наведено у табл. 3 .

Для узагальнення отриманих даних зі зміни хімічних показників (кислотного, перекисного та йодного чисел) в залежності від умов і тривалості зберігання дрібнонасіннєвих олійних культур методом найменших квадратів були отримані наступні математичні моделі:

$$
\text { - ріпаку }
$$

$K \Psi=4,268+0,002 \theta+0,043 \tau+0,001 \theta \cdot \tau$

$\breve{И} \Psi=70,966+0,003 \theta+0,498 \tau+0,012 \theta \cdot \tau$;

$\Pi Ч=3,378+0,001 \theta+0,045 \tau+0,002 \theta \cdot \tau$; - гірчиці

$K \Psi=3,587+0,003 \theta+0,029 \tau+0,003 \theta \cdot \tau ;$ $\breve{И} \Psi=56,248+0,003 \theta+0,709 \tau+0,026 \theta \cdot \tau ;$

$\Pi Ч=1,790+0,003 \theta+0,086 \tau+0,002 \theta \cdot \tau$; - льону олійного

$K \Psi=2,731+0,003 \theta+0,028 \tau+0,002 \theta \cdot \tau ;$ $\breve{И ̆}=61,365+0,001 \theta+0,625 \tau+0,025 \theta \cdot \tau$;

$\Pi Ч=2,144+0,002 \theta+0,072 \tau+0,007 \theta \cdot \tau$; - маку

$K \Psi=3,115+0,001 \theta+0,042 \tau+0,001 \theta \cdot \tau ;(10)$

$\breve{И} \Psi=117,861+0,026 \theta+0,595 \tau+0,026 \theta \cdot \tau ;(11)$

$\Pi Ч=5,075+0,001 \theta+0,049 \tau+0,001 \theta \cdot \tau . .(12)$

де $К Ч$ - кислотне число, мг КОН на 1 г жиру; ЙЧ - йодне число,г $\mathrm{J}_{2}$ на 100 г жиру, ПЧ - перекисне число, моль $\mathrm{O}_{2} /$ кг; $\theta-$ температура, ${ }^{\circ} \mathrm{C} ; \tau-$ тривалість зберігання, місяці.
Наведені математичні моделі справедливі у дослідженому діапазоні зміни тривалості зберігання та температури зберігання насіння гірчиці, ріпаку, льону та маку, що дає можливість використовувати ці моделі для прогнозування показників якості (кислотного, йодного та перекисного чисел) досліджених дрібнонасіннєвих культур при зберіганні.

При зберіганні дрібнонасіннєвих культур протягом 12 місяців показники їх якості не перевищували нормованих значень.

\section{Висновки}

1. Проведений аналіз літературних джерел показав, що в останні роки значно збільшилося надходження на хлібоприймальні підприємства, елеватори і перевантажувальні термінали дрібнонасіннєвих культур, таких як ріпак, гірчиця, льон, почали надходити партії насіння маку. Ці культури дають навіть в посушливі роки високий урожай, який дозволяє господарствам отримувати привабливий прибуток, в тому числі і за рахунок експорту.

Кожна $з$ перерахованих культур має свої унікальні властивості. Слід зазначити, що технологічні властивості вказаних дрібнонасіннєвих культур суттєво відрізняються від зерна традиційних зернових, бобових і олійних культур, і тому необхідно їх детальне вивчення.

2. В даній роботі визначено рівноважну вологість олійних дрібнонасіннєвих культур в залежності від температури та відносної вологості зовнішнього середовища. Встановлено, що при довгостроковому зберіганні дрібнонасіннєвих культур необхідно контролювати відносну вологість повітря, так як при іiі підвищенні підвищується й рівноважна вологість насіння.

3. У роботі визначено показники якості дрібнонасіннєвих культур в залежності від температури і тривалості зберігання. За результатами дослідження складені рівняння залежності кислотного, перекисного та йодного чисел насіння дрібнонасіннєвих олійних культур в залежності від температури та тривалості зберігання. Отримані дані дають можливість прогнозувати зміни їх якості при зберіганні та вибирати безпечні режими зберігання дрібнонасіннєвих культур в залежності від можливостей підприємства.

\section{ЛIТЕРАТУРА}

1. Анискин В.И., Окунь Г.С., Чижиков А.Г. Гигроскопические свойства зерна различных культур. М.: ЦИНТИ Госкомзаг, 1967. $-86 c$.

2. Буранова С.В., Соколовська О.Г. Гігроскопічні характеристики нетрадиційнихзернових культур // Наук.пр. молодих вчен., acn. та студ. ОНАХT. - Одеса, 2009. - C. 126-128.

3. Влага в зерне / А.С. Гинзбург, В.П. Дубровский, Е.Д. Казаков и др. - М.: Колос, 1969. -224 с.

4. Егоров Г.А. Влияние тепла и влаги на прочессы переработки и хранения зерна. - М.: Колос, 1973. - 264 c.

5. Трисвятский Л.А. Хранение зерна. - М.: Агропромиздат, 1986. - 400 c.

6. Станкевич Г.М., Страхова Т.В., Атаназевич В.І. Сушіння зерна: підруч. - К.: Либідь, 1997. - 351 с.

7. Малин Н.И. Технология хранения зерна. - М.: Колос, 2005. - 280 c.

8. Подпрятов Г.І.,. Скалецька Л.Ф, Сеньков А.М. Технологія зберігання і переробки продукиї рослинництва. - К.: Вища освіта, 2004. -272 c.

9. Пузік Л.М., Пузік В.К. Технологія зберігання і переробки зерна: навч. посіб. - Харків: ХНАУ, 2013. - 312 c.

10. За правильного зберігання насіння гірчииі немає для розвитку мікроорганізмів / А. Сгорова, Г. Свдокимова, С. Орлова, В. Тіора // Зерно і хліб. - 2007. - № 1. - С. 27-28.

11. Станкевич Г.М., Овсянникова Л.К., Соколовська О.Г. Обробка та зберігання дрібнонасіннєвих олійних культур: монографія. - Одеса: КП ОМД, 2016. - 128 с.

12. Нечаев А.П., Сандлер Ж.Я. Липиды зерна. - М.: Колос, 1975. - 159 с.

13. Тютюнников Б.Н. Химия жиров. - М.: Пищевая пром-сть, 1974. - 447 с. 
14. Щербаков В.Г., Лобанов В.Г. Биохимия и товароведение масличного сырья. - М.: Колос, 2003. - 360 c.

15. Соколовська О.Г. Розробка ефективних режимів термічної обробки і зберігання дрібнонасіннєвих культур: дис.канд. техн. наук: 05.18.02. - Одеса, 2013. - 191 c.

16. Стародубиева А.И., Сергунов В.С. Практикум по хранению зерна. - М.: Агропромиздат, 1987. - 192 c.

17. Остапчук М.В., Станкевич Г.М. Математичне моделювання на ЕОМ: підруч. - Одеса: Друк, 2006. - 313 c.

\title{
L.K. OVSIYANNIKOVA, Ph.D. Science Associate Professor, E.G. SOKOLOVSKAYA, Ph.D., L.O. VALEVSKAYA, Ph.D. Science Associate Professor, GRISHCHUK J.V., postgraduate Odessa National Academy of Food Technologies, Odessa \\ DETERMINATION OF FACTORS AFFECTING THE ORGANIZATION OF THE PROCESS OF STORAGE OF DRYBONASINNOUS OLIVE CULTURES
}

\begin{abstract}
In the article the study of the change of acid, peroxide and iodine numbers of small-numbered oilseeds in the storage temperature range of $5 \ldots 25^{\circ} \mathrm{C}$ and the storage time up to 12 months has been carried out. It was established that the factors influencing the amount of water absorption by seeds, determining the anatomical structure and chemical composition of the grain. At the same temperature and relative humidity of air, the main and cover tissues of the seed absorb different amounts of moisture from the air.

It is shown that the higher the seed oil, the lower their equilibrium humidity, therefore in high-seeded seeds the moisture content in the hydrophilic part is higher. For oil seeds, the humidity of the hydrophilic part is much higher than the total moisture content. The chemical composition of the hydrophilic part of the seeds of different cultures is different, therefore their moisture absorbing ability is not the same. However, in general, for all crops, the general reciprocal relationship between the content of oil in the seed and the equilibrium moisture remains.

The value of the equilibrium moisture content of the seed depends on the size of the seed: the equilibrium humidity in the small seed is smaller than in the large, due to the relative increased surface of the seed.

The obtained data can be used when choosing conditions for laying small-fruited crops for long-term storage.

For the storage of seeds of oilseeds, not only the content of crude fat, but also the fatty acid composition of the oil, primarily the content of unsaturated fatty acids, matters. Potato spoilage under adverse storage conditions begins with the lipase enzyme that breaks fat on glycerol and free fatty acids. Free fatty acids can react with oxygen and further split, with the formation of intermediate products - hydroperoxides, which can break down further to aldehydes, ketones and simple fatty acids. It is secondary oxidation products that reduce the nutritional value of oil and its deterioration. Oxidation processes occur mainly in unsaturated fatty acids, and the fatty acid composition of the flour seed is $90 \%$ composed of unsaturated fatty acids.
\end{abstract}

When storing small-fruited crops for 12 months, the indicators of their quality did not exceed the normalized values. regimes.

Key words: small-flowered crops, hygroscopic properties, equilibrium humidity, quality indices, storage

\section{REFERENCES}

1. Anyskyn V.I., Okun G.S. Chyzhykov A.G. (1967). Hygroscopic properties different grain. M.: TSYNTY Hoskomzah, 86.

2. Buranova S.V. Sokolovska O.H. (2009). Hygroscopic properties of non-traditional crops. Science. pr. Young Scientists., Asp. and students. / ONAFT, 126-128.

3. Ginzburg A.S.,Dubrovsky V.P., Kazakov E.D. and others (1969). The moisture in the grain. M.: Kolos, 224

4. Egorov G.A. (1973). Effect of heat and moisture in the reprocessing processes and storage. M.: Kolos, 264.

5. Trisvyatsky L.A. (1986). Storage of grain. M.: Agropromizdat, 400.

6. Stankevich G.M., Strakhova T.V., Atanazevich V.I. (1997). Dryinggrain. K.: Lybid, 351.

7. Malin N.I.(2005). Grain storage technology. M.: Kolos, 280.

8. Podpryatov GI, Skaletska L.F, Senkov A.M. (2004). Technology storage and processing of crop production. K .: Higher Education, 272.

9. Puzyk L.M., Puzyk V.K. (2013). Technology of storage and processing of grain. Kharkov: KhAI, 312

10. Egorova A., Yevdokimova G., Orlova S., Tiora V. (2007). Under proper storage nomustard seeds for microbialgrowth. Cereals and bread. 1, 27-28.

11. Stankevich G.M., Ovsyannikova L.K., Sokolovskaya O.G. (2016) Processing and storage of fine grain oil seed culture. Monograph. Odessa: $C P$ OMD, 128.

12. Nechayev A.P., Sandler Z.Y. (1975). Lipids grain. M.: Kolos, 159

13. Tyutyunnikov B.N. (1974) Chemistry fat. M.: Food prom-st, 447.

14. Shcherbakov V.G., Lobanov V.G. (2003). Biochemistry and merchandising oil seeds. M.: Kolos, 360

15. Sokolovskaya O.G. (2013). Development of the effective heat treatment and storage small grain's cultures. Dissertation candidate.Sc.: 05.18.02 O., 191 .

16. Starodubtseva A.I., Sergunov V.S. (1987). Workshop on grain storage. M.: Agropromizdat, 192.

17. Ostapchuk N.V., Stankevich G.M. (2006). Mathematical modeling on computers. O.: Druk, 313.

Надійшла 11.11.2017. До друку 12.12.2017 Адреса для переписки: вул. Канатна, 112, м. Одеса, 65039

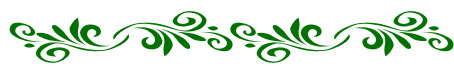

